\title{
APLIKASI PROTEASE DAN PENGARUH SUHU PADA ASIDIFIKASI DIGESTASI ANAEROBIK DUA-TAHAP LUMPUR IPAL BIOLOGI INDUSTRI KERTAS
}

\author{
Sri Purwati a *, Rina S.Soetopo ${ }^{\text {a }}$, Tami Idiyanti ${ }^{\text {b }}$ \\ ${ }^{\text {a }}$ Balai Besar Pulp dan Kertas \\ Jl. Raya Dayeuhkolot 132 Bandung 40258 Telp. (022) 5202980 Fax. (022) 5202871 \\ ${ }^{\mathrm{b}}$ Pusat Penelitian Kimia LIPI, Serpong-Tangerang \\ * e-mail : purwati_sp@yahoo.com \\ Diterima : 12 April 2011, Revisi akhir : 18 Mei 2011

\section{PROTEASE APPLICATION AND TEMPERATURE INFLUENCE IN ACIDIFICATION OF TWO-STAGES ANAEROBIC DIGESTION BIOLOGICAL WASTEWATER SLUDGE OF PAPER INDUSTRY}

\begin{abstract}
The research of two-stage anaerobic digestion process for biological wastewater sludge of paper industry with modification of enzyme application and temperature treatment (mesophilic-thermophilic) has been done at the stage of acidification. Batch experiments were conducted to determine their effectiveness by applying treatment of the retention time (2-12 days) and the amount of inoculum (150-450 $\mathrm{mL} / \mathrm{L})$. They were observed by the performance process of increasing levels of soluble protein, and the formation of volatile organic acids (VFA). The results showed that application of the addition of protease 0.25 units / g. TS sludge at thermophilic temperatures can increase the hydrolysis with an indication of increased levels of soluble protein in supernatant reaching 380\%, whereas in acidification process can improve the formation of organic acids through increased levels of VFA. The best performance of acidification process was found in thermophilic temperature conditions, with retention time of 4 days treatment and the addition of microbial inoculum at $300 \mathrm{~mL} / \mathrm{L}$. Sludge digestion of acidification stage at the condition of 2.25 load g.VS sludge / g.VS microbes.day can produce increased levels of VFA by approximately $624 \%$. The solid produced of $40 \% \mathrm{v} / \mathrm{v}$ contains organic and nutrient elements that can be used as organic fertilizer.
\end{abstract}

Key words : biological wastewater sludge, anaerobic digestion, acidification, protease, thermophilic

\begin{abstract}
ABSTRAK
Penelitian digestasi anaerobik dua-tahap lumpur IPAL biologi industri kertas dengan modifikasi aplikasi enzim dan perlakuan suhu (mesofilik-termofilik) telah dilakukan pada tahap asidifikasi. Percobaan yang dilakukan secara batch ditentukan efektivitasnya melalui perlakuan waktu retensi (2-12 hari) dan jumlah inokulum (150-450 mL/L.) dengan pengamatan kinerja proses terhadap peningkatan kadar protein larut, dan pembentukan asam-asam organik volatile (VFA). Hasil penelitian menunjukkan bahwa aplikasi protease pada penambahan 0,25 unit/g.TS lumpur, pada suhu termofilik dapat meningkatkan hidrolisis, yang ditunjukkan dengan peningkatan kadar protein larut mencapai $380 \%$, sedangkan dalam proses asidifikasi dapat meningkatkan pembentukan asam organik melalui peningkatan kadar VFA. Kinerja proses asidifikasi yang terbaik dijumpai pada kondisi suhu termofilik, dengan perlakuan waktu retensi 4 hari dan penambahan inokulum mikroba $300 \mathrm{~mL} / \mathrm{L}$. Digestasi lumpur tahap asidifikasi pada kondisi tersebut yang berlangsung pada beban 2,25 g.VS lumpur/g.VS mikroba. hari; dapat menghasilkan peningkatan kadar VFA sekitar $624 \%$. Padatan yang dihasilkan sebanyak $40 \%$ v/v mengandung komponen organik dan unsur-unsur nutrisi yang dapat dimanfaatkan sebagai pupuk organik.
\end{abstract}

Kata kunci : lumpur IPAL biologi, digestasi anaerobik, asidifikasi, protease, termofilik 


\section{PENDAHULUAN}

Penanganan limbah padat industri kertas yang berasal dari lumpur Instalasi Pengolahan Air Limbah (IPAL ) biologi sampai saat ini masih menimbulkan masalah karena sifatnya yang voluminous dan sulit dipisahkan dari kandungan airnya. Lumpur biologi tersebut jumlahnya cukup besar sekitar 0,3-1,0 $\mathrm{m}^{3} /$ ton produk dengan kadar padatan 1-2\% (Elliott, 2007). Lumpur biologi dari proses lumpur aktifyang encer dan sulit dipekatkan tersebutkomponen utamanya adalah bahan organik yang didominasi oleh biomassa mikroba dalam bentuk partikel koloid dan berlendir (Deminer et al., 2008). Lumpur dengan kondisi tersebut di atas memerlukan pengolahan yang khusus sebagai alternatif pemecahan masalah agar tidak menimbulkan pencemaran dan dapat memenuhi peraturan lingkungan. Pada dasarnya lumpur yang dihasilkan dari IPAL biologi adalah biomassa organik yang dapat dikonversi oleh mikroba menjadi biogas yang dapat dimanfaatkan sebagai sumber energi alternatif (Bhattacharyya, 2008).

Teknologi digestasi anaerobik adalah salah satu proses yang dapat diaplikasikan untuk penanganan lumpur IPAL biologi sebagai solusi pengelolaan limbah yang memberikan nilai tambah. Penelitian penanganan lumpur IPAL biologi industri pulp dan kertas dengan cara digestasi anaerobik telah dilakukan sebelumnya dan hasilnya cukup prospek untuk dikembangkan (Purwati, 2006 danWood Nicholas, 2008) Namun, karena proses anaerobik sangat kompleks dengan melalui tahapan proses hidrolisis, asidifikasi, dan metanasi, maka kendala yang dihadapi adalah waktu tinggal yang cukup lama dengan konsekuensi ukuran reaktor besar. Penelitian yang dilakukan dengan sistem satu tahap menghasilkan biogas yang masih rendah yaitu sekitar $0,14 \mathrm{~L} / \mathrm{g}$.VS lumpur dengan kadar metan $\left(\mathrm{CH}_{4}\right)$ dalam biogas hanya mencapai $51,5 \%$, disamping waktu yang diperlukan pun cukup lama hingga 30 hari (Purwati, 2006). Rendahnya biogas yang dihasilkan dengan digestasi satu tahap disebabkan karena kedua proses asidifikasi dan metanasi berlangsung dalam satu reaktor sehingga kondisi optimal masing-masing proses yang berbeda tidak dapat tercapai (Solera et al., 2002)

Keberhasilan proses digestasi tergantung pada hasil optimasi kondisi operasi pada masingmasing tahapan proses baik pada proses asidifikasi maupun metanasi sehingga laju produksi biogas maksimal. Penelitian lain yang dilakukan oleh Gijzen (2005) dan Deminer (2008) menjelaskan bahwa digestasi anaerobik dengan sistem dua tahap yang memisahkan antara proses asidifikasi dan metanasi pada reaktor yang berbeda memberikan hasil yang lebih efektif.

Digestasi anaerobik secara umum terbagi atas aktivitas dua grup bakteri yaitu asidogenik dan metanogenik yang memiliki perbedaan signifikan dalam respek fisiologis pertumbuhan dan metabolismenya (Mshandete et al., 2008). Oleh karenanya akan sulit melakukan optimasi terhadap kedua grup bakteri tersebut pada satu digester atau dengan sistem satu tahap. Dengan digestasi anaerobik dua tahap dapat dilakukan pengaturan kondisi operasi sesuai kondisi optimum masingmasing proses agar kinerja hidrolisa - asidifikasi sebagai proses tahap kesatu dan metanasi sebagai proses tahap kedua masing-masing meningkat sehingga produktivitas biogas dan konsentrasi metan menjadi lebih tinggi (Hutnan, 2001).

Pengolahan lumpur dengan digestasi anaerobik sistem dua tahap ini dapat ditingkatkan lagi kinerjanya dengan cara dimodifikasi melalui aplikasi enzim pada proses hidrolisis. Beberapa enzim seperti selulase, amilase, lipase dan protease dapat digunakan untuk mempercepat laju hidrolisis dalam konversi biomassa digestasi anaerobik (Romano,2009). Dengan proses enzimatis substrat yang berupa senyawa organik kompleks tersuspensi dengan molekul besar dapat diubah menjadi organik sederhana molekul kecil yang terlarut sehingga dapat dimetabolisme langsung oleh mikroba. Penelitian dengan menambahkan enzim selulase sebagai pengolahan awal pada digestasi limbah biomassa, dilaporkan dapat meningkatkan hasil biogas dan metan masing-masing $12 \%$ dan 15\% (Romano, 2009). Faktor penting yang mempengaruhi proses hidrolisis ini adalah $\mathrm{pH}$ dan temperatur. Dari beberapa enzim yang digunakan pada penelitian tersebut, salah satu diantaranya yaitu protease, dapat menghasilkan produk hidrolisa yang bersifat mudah larut dan menjadi sumber nutrisi yang digunakan oleh mikroba pembentuk asam asetat. Kinerja enzim protease akan maksimal bila bekerja pada $\mathrm{pH}$ optimumnya 4,5-7,0 dan temperatur dengan kisaran $55-75^{\circ} \mathrm{C}$ (Rina, 2010)

Penelitian telah dilakukan untuk mengkaji efisiensi proses digestasi anaerobik dua-tahap yang dilakukan dalam reaktor terpisah antara proses hidrolisis-asidifikasi pada reaktor pertama 
dan proses metanasi pada reaktor kedua. Tulisan ini melaporkan efektivitas proses hidrolisis asidifikasi dengan pengaruh adanya aplikasi protease dan suhu termofilik - mesofilik, serta beberapa variabel proses untuk menentukan kondisi operasi yang memberikan kinerja terbaik. Data kondisi operasi yang diperoleh dari percobaan laboratorium sistem batch ini digunakan sebagai kondisi awal untuk penelitian lebih lanjut ke skala lebih besar dengan sistem kontinyu (Rina, 2010). Hasil penelitian ini diharapkan dapat digunakan sebagai bahan pertimbangan dalam mendorong pihak industri kertas mengaplikasikan teknologi digestasi anaerobik sebagai upaya pengelolaan lingkungan yang sekaligus memberikan nilai tambah.

\section{BAHAN DAN METODE}

\section{Bahan}

Limbah lumpur yang digunakan dalam penelitian ini adalah lumpur biologi dari IPAL lumpur aktif pabrik kertas yang memproduksi kertas industri dengan bahan baku kertas bekas. Untuk penyediaan lumpur selama percobaan dilakukan 4 kali pengambilan, dan selama penyimpanan dilakukan dekantasi untuk mengatur lumpur pada kadar padatan $2 \%$. Enzim yang digunakan adalah jenis protease dari papain dan ragi Sacharomyces cereviseae dengan aktivitas spesifik 2000 unit/gr, diperoleh dari laboratorium Puslit Kimia LIPI Serpong. Sedangkan sebagai inokulum bakteri asidogenik diperoleh dari pembiakan mikroba kotoran ternak kambing secara anaerobik dalam substrat molase yang sudah diaklimatisasikan lebih dahulu dalam substrat limbah lumpur. Bahan kimia yang digunakan adalah asam fosfat untuk pengatur $\mathrm{pH}$, dan bahan-bahan kimia untuk analisa kadar organik seperti gula, protein, lemak, selulosa, kemudian bahan kimia untuk analisa bahan anorganik nutrisi dan kandungan logam-logam berat, serta bahan kimia untuk analisa Volatile Fatty Acid (VFA), alkalinitas, dan COD.

\section{Peralatan}

Untuk peralatan utama digunakan reaktor digester sistem batch sebanyak 30 set untuk percobaan termofilik (pengatur suhu $55-60^{\circ} \mathrm{C}$ ) dan 30 set untuk percobaan mesofilik (tanpa pengatur suhu) yang berukuran masing-masing volume $2500 \mathrm{ml}$. Pada masing-masing digester dilengkapi dengan botol penampung gas dan air berukuran volume $500 \mathrm{ml}$ untuk pengukuran gas yang terbentuk. Beberapa peralatan pendukung antara lain $\mathrm{pH}$ meter, thermometer, kontainer penampung, dan peralatan uji.

\section{Metode}

Pelaksanaan penelitian dilakukan dalam skala laboratorium dengan percobaan sistem batch yang terdiri dari tahapan kegiatan sebagai berikut :

\section{Karakterisasi Lumpur}

Terhadap lumpur dilakukan analisa beberapa parameter yang berkaitan dengan potensinya sebagai penghasil biogas seperti analisa kadar organik berupa selulosa, protein, gula, lemak, dan kandungan unsur hara/nutrisi seperti $\mathrm{C}$, $\mathrm{N}, \mathrm{P}, \mathrm{K}, \mathrm{Ca}, \mathrm{Mg}, \mathrm{S}, \mathrm{Mn}, \mathrm{Fe}, \mathrm{Cu}, \mathrm{Zn}$, serta yang berkaitan dengan resiko ataupun penghambat berupa analisa logam-logam berat. Metoda analisa menggunakan SNI dan metoda yang mengacu pada standar yang berlaku.

\section{Percobaan Hidrolisis dengan Enzim}

Pada percobaan ini digunakan enzim dari protease yang berasal dari papain dan ragi Sacharomyces cereviseae. Pemilihan jenis protease didasarkan atas pertimbangan bahwa komponen organik utama yang terkandung dalam lumpur biologi adalah protein. Percobaan dilakukan dengan menambahkan enzim pada dosis terbaik (Rina, 2010) sebanyak 0,25 unit/g. total solid (TS) lumpur, ke dalam botol tertutup yang berisi lumpur dengan kadar TS 2\%. Setelah dicampur homogen, diinkubasikan dengan variasi suhu mesofilik atau pada suhu ruang, dan suhu termofilik pada $55^{\circ} \mathrm{C}$ masing-masing selama waktu 4 jam. Pengamatan melalui analisa kadar gula dan protein larut dilakukan setiap 30 menit sekali.

\section{Pembuatan Stok Inokulum}

Inokulum yang dibuat dari kotoran kambing dikembangbiakan pada substrat dari sampah sayuran yang dibuat buburan dengan kepekatan 
$10 \%$. Setelah terbentuk gas, suspensi mikroba sebanyak 10 liter dipindahkan ke dalam botol fermentor tertutup volume 20 liter dan ditambahkan kedalamnya sumber karbon berupa larutan molase sebanyak 1 liter. Proses aklimatisasi dilakukan terhadap pertumbuhan bakteri asidogenik dengan penambahan larutan substrat yang merupakan campuran molase dengan limbah lumpur. Penambahan substrat dilakukan setiap hari dengan komposisi limbah lumpur dalam campuran substrat meningkat secara bertahap, yang pada akhirnya substrat merupakan $100 \%$ limbah lumpur. Stok inokulum yang telah teraklimatisasi ini digunakan sebagai inokulum untuk percobaan.

\section{Percobaan Asidifikasi}

Percobaan asidifikasi dilakukan terhadap limbah lumpur (kadar TS 2\%) yang sudah di hidrolisa selama 4 jam dengan enzim terpilih. Ke dalam botol digester (volume 2 liter) yang sudah berisi limbah hasil hidrolisa enzim, ditambahkan inokulum dengan variasi jumlah penambahan dan pengaturan pada $\mathrm{pH}$ 5, kemudian diinkubasikan dengan variasi waktu, dan perlakuan suhu. Variabel proses percobaan dengan replikasi masing-masing 3 ulangan untuk setiap perlakuan adalah sebagai berikut:

a. Suhu

- Mesofilik

- Termofilik $: 25^{\circ} \mathrm{C}$ (suhu ruang) $: 55^{\circ} \mathrm{C}$

b. Waktu inkubasi, hari

- Untuk suhu mesofilik : 4; 8;12

- Untuk suhu termofilik : $2 ; 4 ; 6$

c. Jumlah inokulum, $\mathrm{mL} / \mathrm{L}: 150 ; 300 ; 450$

\section{Pengamatan dan Evaluasi}

Pengamatan dilakukan setelah akhir inkubasi, dengan memisahkan antara supernatan yang terbentuk dengan sisa lumpur. Larutan supernatan di sampling dan dianalisa yang meliputi parameter $\mathrm{pH}$, VFA, gula terlarut, protein terlarut, dan COD terlarut. Sedangkan terhadap endapan lumpurnya dilakukan analisa, meliputi TS, unsur hara dan kandungan logam berat. Evaluasi dilakukan dengan menganalisis perubahan yang terjadi sebelum dan setelah proses. hidrolisis - asidifikasi, terhadap masingmasing perlakuan, sehingga dapat ditentukan kondisi operasi terbaik.

\section{HASIL DAN PEMBAHASAN}

\section{Karakteristik Limbah Lumpur}

Limbah lumpur yang diperoleh dari IPAL bersifat encer dan voluminus, hal ini terlihat dari kadar padatan ( TS ) yang rendah yaitu sekitar 1,2\%. Kemampuan mengendap lumpur yang lambat, ditunjukkan dari kepekatan lumpur yang selama penyimpanan 48 jam hanya mengendapkan $35 \% \mathrm{v} / \mathrm{v}$ lumpur dengan kepekatan sekitar 2\%. Berdasarkan hasil analisa kimia pada Tabel 1, lumpur biologi yang didominasi biomassa mikroba ini memiliki kandungan bahan organik sekitar $50 \%$ yang sebagian besar merupakan senyawa protein, dan sisanya merupakan organik dari berbagai komponen seperti selulosa, hemiselulosa, lemak dan karbohidrat. Kandungan abu dalam lumpur juga cukup tinggi, hal ini mengindikasikan tingginya kandungan senyawa anorganik yang berupa unsur-unsur nutrisi yang ditambahkan pada proses lumpur aktif maupun yang terbawa oleh bahan baku kertas bekas.

Data analisa pada Tabel 1 menunjukkan bahwa karakteristik limbah lumpur cukup prospektif untuk diolah dengan proses digestasi anaerobik, karena selain mengandung bahan organik, juga mengandung nutrisi makro dan mikro yang diperlukan untuk kehidupan mikroba. Hal ini menjadikan salah satu keuntungan, karena tidak diperlukan lagi penambahan nutrisi pada proses digestasi anaerobik untuk meningkatkan aktivitas bakteri asidogenesis. Bahan organik yang terikat dalam bentuk senyawa kompleks dalam lumpur dapat didegradasi oleh mikroba anaerobik menjadi organik sederhana dan asam-asam organik melalui proses asidifikasi yang akhirnya pada proses metanasi dikonversi menjadi biogas (Medhat, 2004). Selain kandungan bahan anorganik yang berupa nutrisi, limbah lumpur industri kertas juga mengandung kontaminan yang berupa logam berat. Kadar logam berat dalam lumpur dari data analisa menunjukkan nilai sangat rendah jauh dari batas toksik bagi kehidupan mikroba, berarti menunjukkan tidak adanya efek negatif bagi keberlangsungan proses digestasi anaerobik (Gallert, \& Winter, 2005). Walaupun demikian masih diperlukan proses aklimatisasi mikroba terhadap limbah lumpur agar proses biodegradasi berlangsung optimal. 
Tabel 1. Karakteristik Limbah Lumpur Biologi Industri Kertas

\begin{tabular}{|c|c|c|c|c|}
\hline \multirow{2}{*}{ Parameter } & \multirow{2}{*}{ Satuan } & \multirow{2}{*}{ Hasil Uji } & \multicolumn{2}{|c|}{ Persyaratan proses anaerobik ${ }^{1}$} \\
\hline & & & Konsentrasi menghambat & Konsentrasi toksik \\
\hline Kadar air & $\%$ & 98,8 & - & - \\
\hline Padatan total & $\%$ & 1,2 & - & - \\
\hline $\mathrm{pH}$ & - & 6,8 & - & - \\
\hline \multicolumn{5}{|c|}{ Komponen organik : } \\
\hline Organik total & $\%$ & 50,56 & - & - \\
\hline Selulosa & $\%$ & 0,23 & - & - \\
\hline Protein & $\%$ & 19,65 & - & - \\
\hline Lemak & $\%$ & 0,59 & - & - \\
\hline \multicolumn{5}{|l|}{ Kandungan hara : } \\
\hline C- Organik & $\%$ & 0,70 & - & - \\
\hline N-total & $\%$ & 0,04 & - & - \\
\hline $\mathrm{C} / \mathrm{N}$ & $\%$ & 18,00 & - & - \\
\hline $\mathrm{P}_{2} \mathrm{O}_{5}$ & $\%$ & 0,03 & - & - \\
\hline $\mathrm{K}_{2} \mathrm{O}$ & $\%$ & 0,01 & - & - \\
\hline $\mathrm{CaO}$ & $\%$ & 0,29 & - & - \\
\hline $\mathrm{S}$ & $\%$ & 0,01 & - & - \\
\hline $\mathrm{Fe}$ & $\mathrm{mg} / \mathrm{L}$ & 8,62 & - & - \\
\hline $\mathrm{Mn}$ & $\mathrm{mg} / \mathrm{L}$ & 1,45 & - & - \\
\hline \multicolumn{5}{|l|}{ Logam berat : } \\
\hline $\mathrm{Cr}$ & $\mathrm{mg} / \mathrm{L}$ & 0,314 & 110 & 420 \\
\hline $\mathrm{Zn}$ & $\mathrm{mg} / \mathrm{L}$ & 3,033 & 400 & 600 \\
\hline $\mathrm{Cu}$ & $\mathrm{mg} / \mathrm{L}$ & 1,623 & 40 & 70 \\
\hline $\mathrm{Cd}$ & $\mathrm{mg} / \mathrm{L}$ & 0,002 & - & $>20$ \\
\hline $\mathrm{Ni}$ & $\mathrm{mg} / \mathrm{L}$ & 0,279 & 10 & 30 \\
\hline Co & $\mathrm{mg} / \mathrm{L}$ & 0,055 & - & - \\
\hline $\mathrm{Pb}$ & $\mathrm{mg} / \mathrm{L}$ & 0,575 & 250 & $>340$ \\
\hline
\end{tabular}

Sumber: ${ }^{1}$ The Biogas Technology in China (1989)

\section{Aplikasi Enzim pada Proses Hidrolisa}

Limbah lumpur biologi yang digunakan pada penelitian ini berupa organik kompleks yang sebagian besar merupakan biomasa sel mikroba dengan kadar protein cukup tinggi sekitar $19,65 \%$. Untuk mempercepat proses hidrolisa ditambahkan enzim yang akan membantu penguraian bahan organik kompleks melalui pemecahan sel mikroba. Hidrolisa protein dapat digunakan enzim protease, yang pada penelitian ini berasal dari papain dan ragi hidup Sacharomyces cereviseae . Kerja protease menghidrolisa protein kompleks menjadi asam amino yang larut dalam air, yang kemudian digunakan sebagai substrat oleh bakteri pembentuk asam-asam organik (asidogenesis dan asetogenesis). Percobaan aplikasi enzim pada proses hidrolisa dilakukan dengan dosis penambahan 0,25 unit/g TS lumpur, dari kedua protease baik papain maupun ragi. Hasil hidrolisa menunjukkan terjadinya kenaikan kadar protein larut dan kadar gula yang dapat dilihat pada Gambar 1 dan 2 memberikan hasil lebih tinggi pada penggunaan protease papain dari pada ragi, walaupun tidak cukup signifikan. Sehingga pada percobaan selanjutnya digunakan protease-papain yang dibuat dari getah papaya, dengan dasar pemilihan adalah selain protease papain memiliki kisaran kondisi operasi suhu dan $\mathrm{pH}$ yang lebih luas, juga pertimbangan proses ketersediaan dan kepraktisan serta nilai ekonomi yang lebih baik dari protease ragi. 


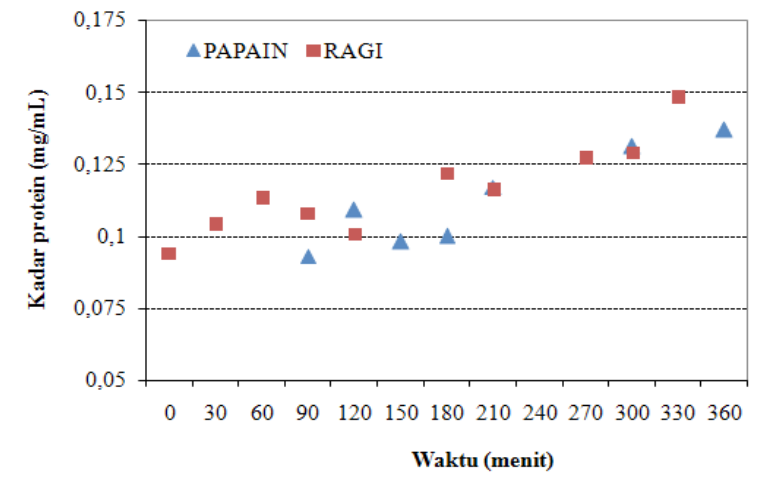

Gambar 1. Kadar Protein Larut Hasil Hidrolisa Protease

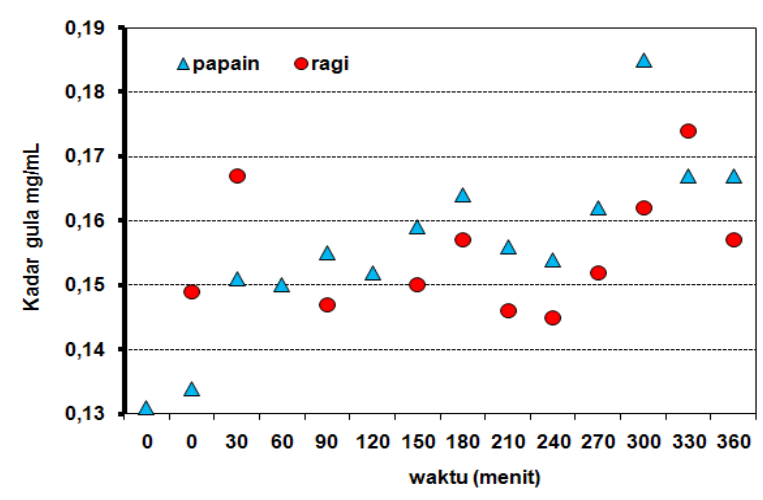

Gambar 2. Kadar Gula Hasil Hidrolisa Protease

Percobaan selanjutnya dilakukan untuk mengetahui pengaruh suhu pada aktivitas enzim protease-papain, dengan mengkondisikan proses hidrolisa pada suhu mesofilik $25^{\circ} \mathrm{C}$ dan suhu termofilik $55^{\circ} \mathrm{C}$. Pada Gambar 3 terlihat bahwa kenaikan kadar protein larut pada suhu termofilik lebih tinggi secara signifikan bila dibandingkan dengan yang terjadi pada suhu mesofilik. Sejalan dengan makin lama waktu hidrolisa, pada kondisi termofilik menunjukkan kenaikan kadar protein larut mencapai hingga $380 \%$ setelah terhidrolisa selama 300 menit atau 5 jam, seperti dapat dilihat pada Gambar 3. Hasil hidrolisa dengan aplikasi enzim pada suhu termofilik ini menunjukkan proses yang lebih baik, yaitu dengan terbentuknya flok yang bersifat hidrofobik dan meningkatnya fraksi protein larut yang berupa supernatan jernih, sehingga fraksi cairan dan endapan mudah dipisahkan. Sedangkan hasil hidrolisa yang dilakukan pada suhu mesofilik tidak menunjukkan adanya kenaikan kadar protein, ditandai dengan fraksi lumpur dan cairan yang sulit dipisahkan.

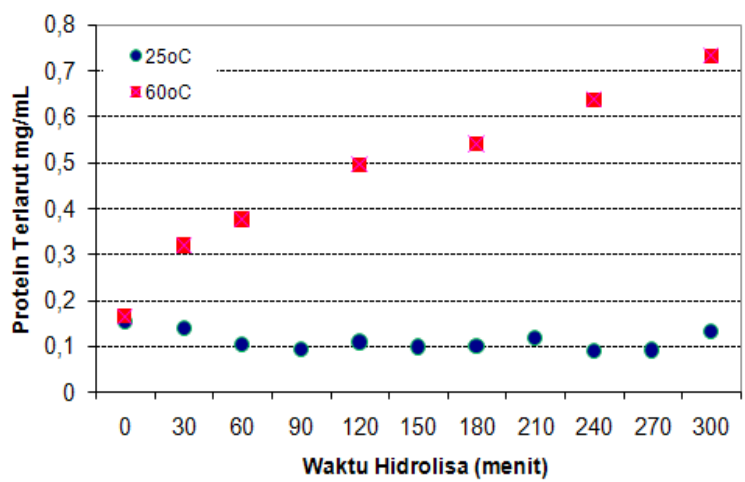

Gambar 3. Hidrolisa Protease - Papain pada Suhu Mesofilik dan Termofilik

\section{Hasil Proses Hidrolisa - Asidifikasi}

Percobaan asidifikasi dalam penelitian ini dilakukan setelah limbah lumpur mendapat perlakuan aplikasi enzim pada dosis penambahan 0,25 unit/g TS lumpur. Setelah proses hidrolisa selama 4 jam, limbah lumpur diberi perlakuan penambahan inokulum yang sudah teraklimasi, dan diinkubasikan dengan variasi waktu dan variasi jumlah mikroba serta dikondisikan dengan variasi suhu mesofilik dan termofilik. Setelah akhir percobaan sesuai dengan perlakuan waktu inkubasinya, dilakukan pengamatan dan analisa terhadap fraksi larutan/supernatan dan padatan hasil asidifikasi dari masing-masing perlakuan, meliputi parameter yang mengindikasikan keberhasilan proses. Parameter-parameter pengamatan tersebut diantaranya adalah $\mathrm{pH}$, kadar protein larut, kadar Volatile Fatty Acid (VFA), endapan lumpur hasil asidifikasi.

\section{Pengamatan pH}

Pada awal proses, campuran lumpur dalam digester diatur pada kondisi optimum sekitar $\mathrm{pH}$ 5. Pada pengamatan $\mathrm{pH}$ setelah asidifikasi, terdapat perubahan $\mathrm{pH}$ yang menunjukkan perbedaan signifikan antara perlakuan suhu mesofilik dan termofilik seperti terlihat pada Gambar 4. Dari pengamatan $\mathrm{pH}$ pada hasil asidifikasi dengan adanya pengaruh suhu menunjukkan perbedaan yang signifikan, yaitu dari $\mathrm{pH}$ awal 5,0-5,5 menjadi meningkat hingga pada kisaran $\mathrm{pH} 7,2-7,8$ untuk kondisi termofilik, sedangkan pada suhu mesofilik $\mathrm{pH}$ sedikit meningkat dalam kisaran $\mathrm{pH}$ 5,5-6,9. 
Dalam proses asidifikasi, populasi bakteri yang ada melakukan penguraian substrat organik kompleks menjadi asam-asam organik, dan sejalan dalam reaksi tersebut juga terjadi pembentukan gas-gas seperti $\mathrm{H}_{2}, \mathrm{CO}_{2}, \mathrm{NH}_{3}$. Peningkatan $\mathrm{pH}$ yang terjadi merupakan hasil dari penguraian protein yang keberadaannya sebagai substrat organik adalah dominan, sehingga dalam pembentukan asam organik sekaligus melepaskan gas $\mathrm{NH}_{3}$ yang mudah larut dan bersifat alkalis. Peningkatan $\mathrm{pH}$ yang lebih tinggi dari hasil asidifikasi pada suhu termofilik, menunjukkan bahwa aktifitas enzim dalam proses hidrolisa dan mikroba asidogenesis lebih efektif dibandingkan dengan proses yang terjadi pada suhu mesofilik.

Perlakuan waktu inkubasi dan jumlah inokulum terhadap $\mathrm{pH}$ larutan seperti yang terlihat pada Gambar 4 menunjukkan kecenderungan naiknya pH sejalan dengan meningkatnya waktu inkubasi dan jumlah inokulum. Namun pada suhu termofilik perlakuan jumlah inokulum kurang menunjukkan adanya perbedaan, kecenderungan hasil terbaik diperoleh pada perlakuan waktu inkubasi 4 hari.

\section{Pengamatan Kadar Protein Larut}

Mekanisme reaksi yang berlangsung selama proses digestasi limbah lumpur diawali dengan aktivitas protease yang berperan menghidrolisa protein kompleks dalam bentuk padatan tersuspensi menjadi asam amino dan peptide yang bersifat larut dalam air (Gallert \& Winter, 2005). Bahan organik kompleks dengan molekul besar lainnya seperti polisakarida terhidrolisa menjadi organik molekul-molekul kecil bentuk gula sederhana yang terlarut sehingga dapat dimetabolisma oleh bakteri asidogenesis. Hasil dari proses hidrolisa tersebut menyebabkan meningkatnya kadar organik terlarut dalam limbah lumpur, selain pembentukan flok dari padatan tersuspensi sehingga menjadi mudah mengendap.

Pengaruh suhu pada proses hidrolisa-asidifikasi terlihat dari intensitas pemisahan fraksi larutan dan padatan pada perlakuan termofilik menunjukkan lebih tinggi dengan diperolehnya $40 \% \mathrm{v} / \mathrm{v}$ endapan dan $60 \%$ v/v cairanjernih. Sedangkanpadaperlakuan suhu mesofilik memberikan cairan supernatan keruh dan koloid yang sulit dipisahkan dari endapannya. Hasil analisa supernatan terhadap parameter kadar protein larut dapat dilihat pada Gambar 5.

Hasil analisa terhadap kadar protein larut menunjukkan bahwa proses hidrolisa dan asidifikasi masih berlangsung secara paralel, produk hidrolisa yang berupa protein larut dan gula menjadi substrat bagi bakteri asidogenesis yang menguraikan menjadi asam-asam organik volatile yang keseluruhannya terdeteksi sebagai parameter VFA. Sejalan dengan perolehan supernatan pada perlakuan suhu termofilik yang lebih baik dibandingkan perolehan pada suhu mesofilik, maka hasil analisa kadar protein larut (Gambar 5) juga menunjukkan keadaan yang sama. Menurut Deminer (2008), suhu tinggi dapat meningkatkan kinerja enzim dalam proses hidrolisa, dan daya degradasi yang lebih tinggi dan cepat pada bakteri asidogenesis sehingga dapat meningkatkan kinerja bakteri metanogenik pada proses metanasi selanjutnya.
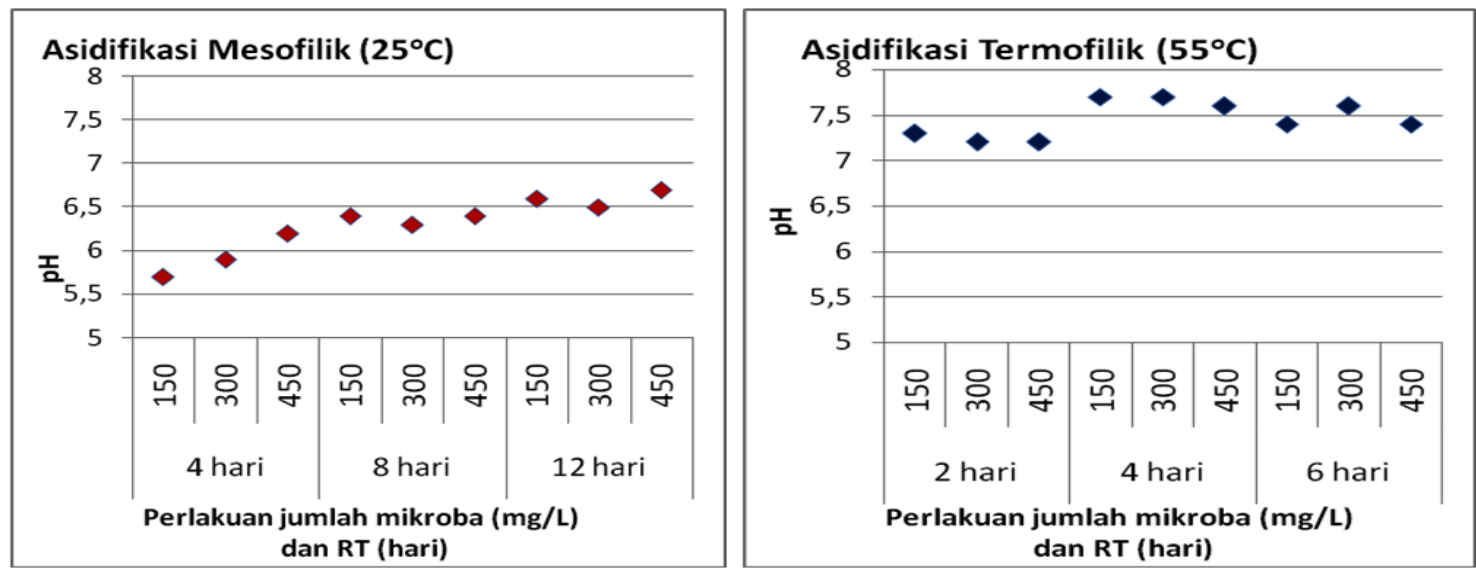

Gambar 4. Pengamatan $\mathrm{pH}$ Hasil Percobaan Asidifikasi 


\section{Pengamatan Kadar Volatile Fatty Acid (VFA)}

Keberhasilan proses asidifikasi dapat dilihat dari tingkat pembentukan asam-asam organik rantai pendek yang berupa asam butirat, asam propionat dan asam asetat yang keseluruhannya dideteksi dengan analisa kadar VFA.

Parameter VFA ini menunjukkan adanya aktivitas bakteri asidogenik dalam mengkonversi senyawa-senyawa protein, selulosa, glukosa dan monosakarida lain sebagai hasil hidrolisis menjadi asam-asam organik volatil.

Dari Gambar 6, terlihat bahwa seluruh hasil perlakuan percobaan yang dikondisikan pada suhu termofilik memberikan kadar VFA jauh lebih besar (290-900 mg/L) dari yang diperoleh pada kondisi suhu mesofilik (12-115 mg/L). Besarnya kadar VFA dalam percobaan ini tidak menjadikan nilai $\mathrm{pH}$ menurun, karena pembentukan asam organik atau VFA dari substrat limbah lumpur yang dominan protein diikuti oleh pelepasan gas amoniak $\mathrm{NH}_{3}$ yang larut dan bersifat basa sehingga dapat menetralisir $\mathrm{pH}$ cairan yang awalnya diatur pada kondisi sedikit asam.

Perlakuan jumlah inokulum $(150-450 \mathrm{~mL} / \mathrm{L})$ yang dikombinasikan dengan waktu inkubasi, relatif tidak menunjukkan pengaruh terhadap pembentukan VFA bila dibandingkan dengan pengaruh lamanya waktu inkubasi. Untuk jumlah inokulum $150 \mathrm{~mL} / \mathrm{L}$ menunjukkan dengan makin lama waktu inkubasi akan memberikan kadar VFA makin tinggi, namun untuk jumlah inokulum $450 \mathrm{~mL} / \mathrm{L}$ cenderung mengalami penurunan kadar VFA. Hal ini dipengaruhi oleh menurunnya beban lumpur yang merupakan rasio antara besarnya substrat dengan jumlah mikroba.

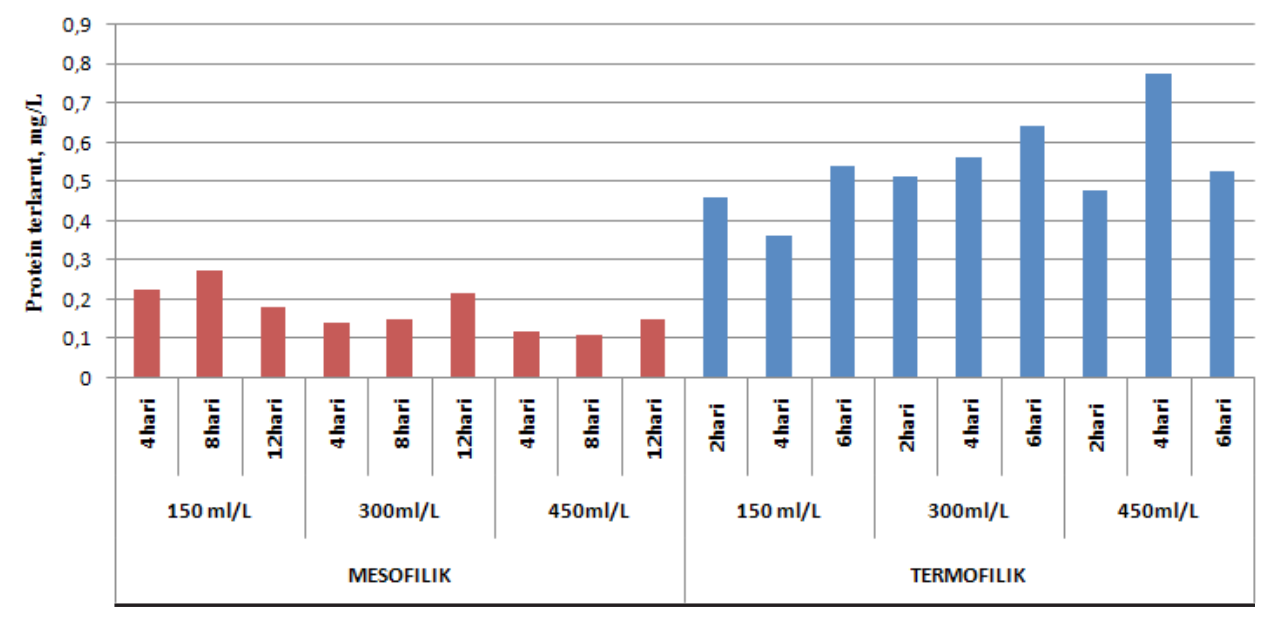

Gambar 5. Kadar Protein Larut setelah Proses Asidifikasi

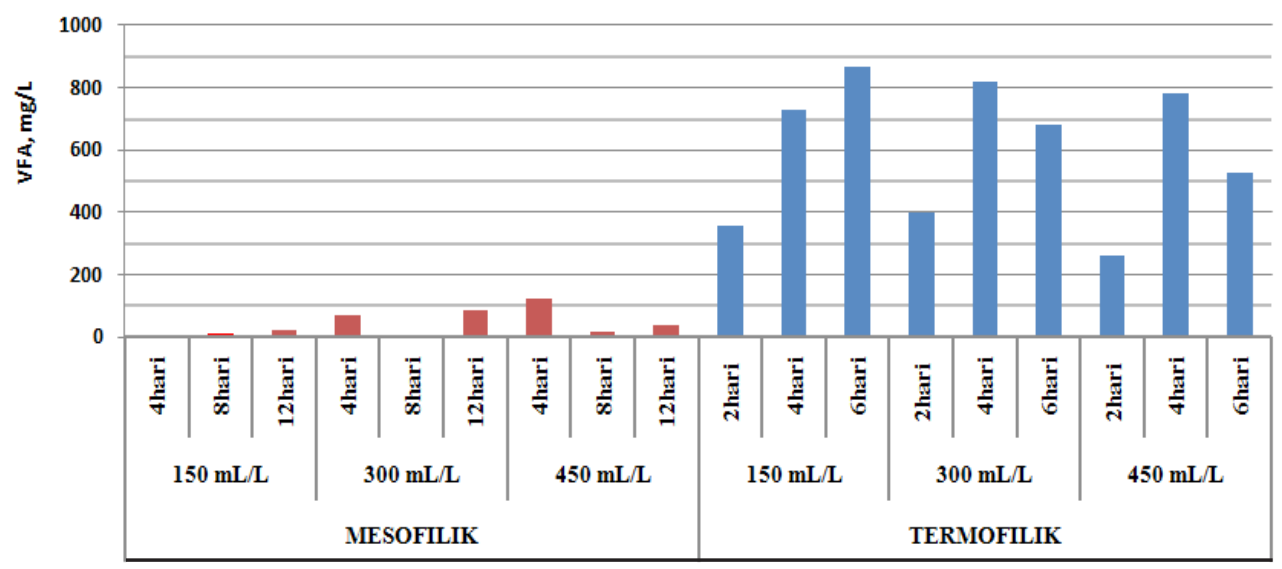

Gambar 6. Kadar VFA Rata-Rata dalam Supernatan Hasil Proses Asidifikasi 
Perlakuan proses asidifikasi yang dikondisikan pada suhu termofilik maupun mesofilik terhadap laju beban organik lumpur ditampilkan pada Gambar 7. Makin rendah beban lumpur menunjukkan kompetisi yang terjadi diantara mikroba dalam mendapatkan substrat menjadi makin tinggi, hal ini dapat mengakibatkan penurunan aktivitas dan efektivitas asidifikasi. Berdasarkan analisis kadar VFA, maka perlakuan yang memberikan hasil terbaik diperoleh dari percobaan yang dikondisikan pada suhutermofilik, dengan penambahan inokulum $300 \mathrm{~mL} / \mathrm{L}$ dan waktu inkubasi 4 hari. Kondisi operasi tersebut berlangsung pada laju beban lumpur 3,76 g VS lumpur/ L.hari atau 2,25 g VS lumpur/ gVS mikroba.hari, yang menghasilkan kadar VFA rata-rata dari $112 \mathrm{mg} / \mathrm{L}$ menjadi $818 \mathrm{mg} / \mathrm{L}$ atau memberikan peningkatan sebesar $624 \%$.

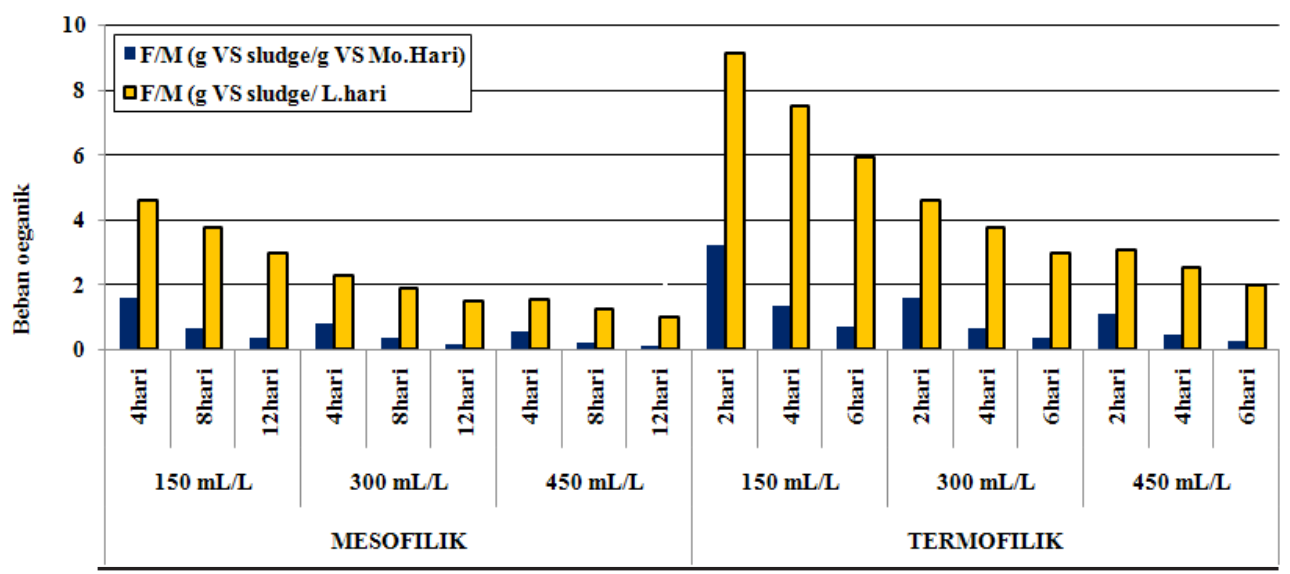

Gambar 7. Beban Organik Lumpur Perlakuan Proses Asidifikasi

Tabel 2. Analisis Komponen Hara Endapan Lumpur Hasil Asidifikasi

\begin{tabular}{lcccc}
\hline \multirow{2}{*}{ Parameter } & Satuan & Hasil Uji & \multicolumn{2}{c}{ Persyaratan Kompos } \\
\cline { 4 - 5 }${ }^{1}$ & & Perhutani $^{2}$ \\
\hline Kadar air & $\%$ & 93,3 & & \\
Padatan total & $\%$ & 6,7 & & \\
$\mathrm{C}-$ Organik & $\%$ & 12,7 & $9,8-32$ & $6,6-8,2$ \\
$\mathrm{~N}-$ Total & $\%$ & 1,2 & 0,4 & $0,6-2,1$ \\
$\mathrm{C} / \mathrm{N}$ & $\%$ & 10,0 & $10-20$ & $10-20$ \\
$\mathrm{P}_{2} \mathrm{O}_{5}$ & $\%$ & 0,5 & 0,1 & $0,3-1,8$ \\
$\mathrm{~K}_{2} \mathrm{O}$ & $\%$ & 1,2 & 0,2 & $0,2-1,4$ \\
$\mathrm{CaO}$ & $\%$ & 5,5 & - & $2,7-6,2$ \\
$\mathrm{MgO}$ & $\%$ & 0,1 & - & $0,3-1,6$ \\
$\mathrm{Fe}$ & $\mathrm{mg} / \mathrm{kg}$ & 582 & & \\
$\mathrm{Mn}$ & $\mathrm{mg} / \mathrm{kg}$ & 44 & - & $220-654$ \\
$\mathrm{Cu}$ & $\mathrm{mg} / \mathrm{kg}$ & 44 & 100 & - \\
$\mathrm{Zn}$ & $\mathrm{mg} / \mathrm{kg}$ & 15 & 500 & $513-2015$ \\
\hline
\end{tabular}

${ }^{1}$ SNI 19-7030-2004, Spesifikasi Kompos dari Sampah Organik Domestik

${ }^{2}$ Standar Unsur Hara Kompos, Perhutani 2001 


\section{Endapan Lumpur Hasil Asidifikasi}

Pengaruh suhu termofilik pada hasil asidifikasi dari digestasi anaerobik dua tahap selain dapat meningkatkan laju biodegradasi mikroba dalam pembentukan VFA, juga memberikankemampuan laju pengendapan partikel padatan lebih cepat sehingga terjadi pemisahan antara cairan supernatan dan endapan lumpur secara nyata.

Hasil analisa endapan lumpur yang ditampilkan pada Tabel 2 menunjukkan bahwa lumpur yang dihasilkan dari proses asidifikasi mengandung komponen hara yang memiliki potensi sebagai pupuk.

Ditinjau dari kadar padatannya maka endapan lumpur hasil asidifikasi menjadi bersifat mudah dipisahkan dari kandungan airnya, terlihat adanya peningkatan kadar padatan dari semula 1,2\% (Tabel 1) menjadi 6,7\% ( Tabel 2). Potensi lumpur sebagai pupuk organik atau kompos ini ditunjukkan dengan adanya nilai $\mathrm{C} / \mathrm{N}$ rasio, kandungan unsurunsur hara makro C,N,P,K yang cukup tinggi, dan hara mikro yang cukup tersedia. Dibandingkan terhadap persyaratan SNI kompos sampah organik domestik dan persyaratan menurut Perhutani (Tabel 2), endapan lumpur hasil asidifikasi memberikan prospek untuk dikembangkan menjadi produk pupuk organik yang mempunyai nilai ekonomi.

\section{KESIMPULAN}

Karakteristik limbah lumpur IPAL biologi industri kertas bersifat voluminous dengan kandungan komponen organik utama berupa protein, dan anorganik nutrisi memberikan prospek untuk diolah dan dimanfaatkan. Pengolahan lumpur dengan cara digestasi anaerobik dua tahap dapat menghasilkan produk biogas yang dapat dimanfaatkan sebagai energi alternatif, dan sisa endapan lumpur yang dapat dimanfaatkan sebagai produk pupuk organik.

Aplikasi enzim protease dan kondisi suhu termofilik dalam proses hidrolisa-asidifikasi dapat meningkatkan kinerja biodegradasi bakteri asidogenesis. Penambahan enzim dosis 0,25 unit/g TS lumpur, dengan waktu hidrolisa 4 jam, pengaturan $\mathrm{pH}$ 5,0-5,5 dan suhu $55^{\circ} \mathrm{C}$, serta beban organik lumpur 3,76 g VS lumpur/L,hari atau 2,25 gVS lumpur/ gMO.hari, dan dengan waktu tinggal 4 hari menunjukkan hasil terbaik dengan peningkatan kadar VFA mencapai $624 \%$.
Hasil digestasi limbah lumpur dari proses hidrolisa-asidifikasi dengan kondisi suhu termofilik membentuk fraksi padatan dan fraksi cairan yang mudah dipisahkan. Supernatan digester asidifikasi dengan hasil $60 \% \mathrm{v} / \mathrm{v}$ berupa organik terlarut VFA diolah lebih lanjut dalam digester metanasi. Sedangkan fraksi padatan atau endapan sebanyak $40 \% \mathrm{v} / \mathrm{v}$ mengandung komponen organik dan anorganik sebagai unsur-unsur hara yang berpotensi untuk dimanfaatkan sebagai pupuk organik.

\section{DAFTAR PUSTAKA}

Bhattacharyya JK., Sunil Kumar, 2008, Studies on Acidification in Two Phase Biomethanation Process of Municipal Solid Waste, Waste Management, Vol. 28, 164 -169.

Deminer, 2008, Two phase thermophilic and mesophilic methanogenesis anaerobic digestion of waste activated sludge, Environmental Engineering Science, Vol. 25 No. 9, $1291-1300$

Elliot. A. \& Talat M., 2007, Pre treatment Technologies for Advancing Anaerobic Digestion of Pulp and Paper Biotreatment Residues, Water Research, Vol.41,4273-4286

Gallert. C, Winter. J, 2005, Bacterial Metabolism in Wastewater Treatment System, Willey VCH Verlag Gmbh \& Co. Kga. Weinheim.

Hj. Gijzen, 2005, Anaerobic Degradation of Papermill Sludge in Two Phase Digester, Journal Biotec, Vol. 23 No. 1

Hutnan, M., 2001, Two - Step Pilot Scale Anaerobic Treatment of Sugar Beet Pulp, Polish Journal of Environtmental Studies, Vol. 10 No. 4, $237-243$

Medhat, M.A., Saleh, Usama FM., 2004, Anaerobic Digestion Technology for Industrial Wastewater Treatment, $8^{\text {th }}$ International Water Technology Conference IWTC, Alexandria , Egypt

Mshandete, Anthony Manoni, 2008, Two Stage Anaerobic Digestion of Sisal Leaf Decortications Residues : Hydrolyses Activities and Biogas Production Profile, African Journal of Biochemistry Research, Vol. 2, Nov, $211-218$

Purwati, S., Rina, S. Soetopo, 2006, Produksi Biogas dan Pupuk Organik Hasil Digestasi Anaerobik Limbah Lumpur IPAL Industri Kertas, Berita Selulosa, Vol. 41 Hal. 1, 30 -36 
Romano Rowena T., Ruitong Zhang, Sarah Teter, 2009, The Effect of Enzyme Addition on Anaerobic Digestion of Jose Tall Wheat Grass, Bioresource Technology, 100 , 4564 4571

Solera, R., Romero, D., Sales, 2002, The Evolution of Biomass in a Two-Phase Anaerobic Treatment Process During Start -Up, Chem. Biochem. Engineering, Vol. 16 No. 1, 25-29
Soetopo, Rina S., Purwati, S., Krisna Aditya W., 2010, Produksi Biogas Sebagai Hasil Pengolahan Limbah Lumpur Industri Kertas dengan Proses Digestasi Anaerobik DuaTahap, Jurnal Riset Industri, Vol. IV Hal. 3, $11-20$

Wood, Nicholas, 2008, Pre treatment of Pulp Mill Wastewater Treatment Residues to Improve Their Anaerobic Digestion, Departement of Chemical Engineering and Applied Chemistry, University of Toronto, Thesis. 